\title{
地球内部の水とその分配
}

Distribution of Water in the Earth's Interior

\section{井上 徹}

Toru INOUE

\begin{abstract}
Water is the most abundant volatile component on the Earth's surface, and it is important to clarify the water distribution in the Earth's interior because water influences the physical properties and melting temperature of minerals. Here the author reviews our recent works about the $\mathrm{H}_{2} \mathrm{O}$ partitioning among high-pressure polymorphs of olivine. Based on the partitioning results combining with the seismological constraint, the author discusses the amount of water distribution in the Earth's interior.
\end{abstract}

$\left[\mathrm{H}_{2} \mathrm{O}\right.$, partitioning, mantle, hydrous wadsleyite, hydrous ringwoodite, phase transition $]$

1.はじめに

水は地球のかけがえのない成分の 1 つであり，そ の存在状態や存在量を知ることはきわめて重要であ る。なぜなら，水は地球の進化過程でユニークな振 る舞いをし，地球の分化・物質移動に多大な影響を 及ぼしてきたと考えられるからである。このような 理由から, 近年, 地球内部物質における水の影響に 関する研究が精力的に行なわれ, 水はどのような条 件で流体相として存在するか, また含水相中に固定 されるか, さらに含水相の融点はどのくらいで何 ${ }^{\circ} \mathrm{C}$ 以上になれば水は液相中に存在するか等が明らかに されてきている。しかし，未だに地球内部には実際 に水が存在するのか, あるいは存在するとしたらど こでどのくらいなのか，という疑問に答えられては いない。

筆者はこの問題を解明すべく, 今まで含水条件下 での各種の実験的研究を行ってきた。その中で本小 論では, 地球内部での相対的な水の存在量, さらに は含水量を見積もる手段としてどのようなパラメー 夕が重要かを述へ, 地球内部の水の存在量を見積も る一例を紹介したいと思う。地球内部での水の議論 については筆者の今までの総説がいくつかあるので 同時にそちらも参照されたい[1-4]。

\section{2. 地球始源物質の含水量}

地球は隕石の集積で形成されたと考えられている が，では地球形成物質の含水量はどのくらいであろ うか。隕石の中で最も始源的な隕石は C1 コンドラ イトであり，その中の Orgueil には約 $20 \mathrm{wt} \%$ \% 水が含まれている。地球はこの C1 コンドライトの みで形成されたとは考えにくいが，この隕石の存在 により, 地球の水はこれらの隕石によりもたらされ たことは明らかである。Ringwood[5]では地球は隕 石の低温凝縮物 $\mathrm{C} 1$ コンドライトと高温凝縮物エン スタタイトコンドライトの混合物（割合は $1 ： 9$ ) で形成されたと考えており，これを採用し単純に初 期地球物質の含水量を見積もると約 $2 \mathrm{wt} \%$ になる。 一方現在の海水の質量は約 $1.4 \times 10^{21} \mathrm{~kg}$ であるから, 現在の含水量は地球全体の $0.02 \mathrm{wt} \%$ となる。地球 形成期には幾分かの水が大気圈外に放出されたこと は容易に想像できるが，この 2 桁の違いを埋めるほ ど放出されたかは謎であり, 地球内部のある層に水 が固定されていることも考えられる。

実際，地球初期に形成されたマグマオーシャン中 には大気との溶解平衡により, 約 $1 \mathrm{wt} \%$ \% $\mathrm{H}_{2} \mathrm{O}$ がマグマオーシャン中に溶け込んだという見積もり あある $[6] 。 \mathrm{H}_{2} \mathrm{O}$ がマグマオーシャンに溶け込む議 論は Abe and Matsui[7,8], Kuramoto and Matsui[9] でもなされている。このマグマオーシャンの冷却に

干790-8577 愛媛県松山市文京町 2-5 愛媛大学地球深部ダイナミクス研究センター Geodynamics Research Center, Ehime University, Bunkyo-cho 2-5, Matsuyama 790-8577, Ehime Electronic address: inoue@sci.ehime-u.ac.jp 
従って, リキダス相として結晶化する鉱物に水が取 り込まれ, 地球内部では十分高温であるため熱力学 的に平衡な状態で, $\mathrm{H}_{2} \mathrm{O}$ が各鉱物間で存在している と考えられる。また現在では沈み込むスラブによっ て水は絶えずマントルに注入されており，このスラ ブが沈み込んでいる場所では周囲のマントルより含 水量が高くなっている可能性もある。次の章では地 球内部でのこの $\mathrm{H}_{2} \mathrm{O}$ の分配について考察する。

\section{3. 地球内部での水の分配}

地球の上部マントルはカンラン石, キ石, ザクロ 石が主要構成鉱物であり，これらの鉱物中に含まれ 得る含水量を実験的に求めることはきわめて重要で ある。最近の実験結果によると, キ石, ザク口石, 及びその高圧相にはほとんど水が結晶中に含まれな いが，カンラン石の高压相である wadsleyite, ringwoodite には最大 $3 \mathrm{wt} \%$ あ水が結晶構造中に 含まれ得ることが明らかになっている[e.g. 10, 11]。 (この相を hydous wadsleyite, hydrous ringwoodite と 呼ぶことにする。）特にカンラン石は上部マントル の構成鉱物の中で約 $60 \%$ 占めるので，これらの 高圧相中の水は遷移層で非常に重要である。これら の相はマントルジオサームに沿った条件でも安定で あり, 大部分の一般的なマントルで存在している可 能性が強い。

このように一般的なマントルでは，これらマント ル遷移層を構成している鉱物に相対的に多く水が含 まれる。ではその程度はどのくらいであろうか。最 近，我々は，このカンラン石の高圧相転移における 水の分配について実験的に決定したのでその結果に ついて紹介する。

\section{1 olivine-wadsleyite 相転移における水の分配}

この相転移境界は $410 \mathrm{~km}$ 地震波速度不連続面に 対応していると考えられており，上部マントルーマ ントル遷移層間の水の分配に対応する。

実験は $\left(\mathrm{Mg}_{0.9} \mathrm{Fe}_{0.1}\right)_{2} \mathrm{SiO}_{4}$ 組成のカンラン石に水を 加えた系で行なった。olivine と wadsleyite の共存領 域で実験を行ない，これらの共存相それぞれの含水 量を二次イオン質量分析計で分析した。結果は Table 1. に示す通りで, olivine-wadsleyite 間の水の 分配は約 $1: 5$ となった[12]。すなわち, $410 \mathrm{~km}$ 不 連続面を介して，上部マントルよりマントル遷移層 の方に水が 5 倍多く含まれることになる。
Table 1. $\mathrm{H}_{2} \mathrm{O}$ partitioning between olivine $(\alpha)$ and wadsleyite $(\alpha), T=1200^{\circ} \mathrm{C}$.

\begin{tabular}{ccccc}
\hline \multirow{2}{*}{ Run No. } & Pressure & \multicolumn{2}{c}{$\mathrm{H}_{2} \mathrm{O} w \mathrm{wt} \%$} & \multirow{2}{*}{$K_{d}$} \\
\cline { 3 - 4 } & $(\mathrm{GPa})$ & $\alpha$ & $\beta$ & \\
\hline 3061 & 13.0 & 0.37 & 1.9 & 5.1 \\
2837 & 13.05 & 0.71 & 3.4 & 4.8 \\
2847 & 13.1 & 0.64 & 3.4 & 5.3 \\
3064 & 13.1 & 0.55 & 2.5 & 4.6 \\
average & & & & $5.0(3)$ \\
\hline
\end{tabular}

$K_{d}=\left(\mathrm{H}_{2} \mathrm{O}\right)_{\beta} /\left(\mathrm{H}_{2} \mathrm{O}\right)_{\alpha}$

modified from Chen et al.(2002)

\section{2 wadsleyite-ringwoodie 相転移における水の分 配}

この相転移境界は $520 \mathrm{~km}$ 地震波速度不連続面に 対応していると考えられており，マントル遷移層の 上半分と下半分の間の水の分配に対応する。

実験は $\left(\mathrm{Mg}_{0.8} \mathrm{Fe}_{0.2}\right)_{2} \mathrm{SiO}_{4}$ 組成のカンラン石に水を 加えた系で行なった。 wadsleyite と ringwoodite の共 存領域で実験を行ない，これらの共存相それぞれの 含水量を二次イオン質量分析計で分析した。結果は Table 2. に示す通りで, wadsleyite-ringwoodite 間の 水の分配は約 $2: 1$ となった。すなわち, $520 \mathrm{~km}$ 不 連続面を介して，マントル遷移層の上部の方に水が 約 2 倍多く含まれることになる。

この分配については，デー夕は 1 つの条件に限ら れるがKLB-1ペリドタイトを出発物質とした実験 からも得られており，その分配は $5: 2$ である。こ の值は今回見積もられた值とほぼ一致する[13]。

Table 2. $\mathrm{H}_{2} \mathrm{O}$ partitioning between wadsleyite $(\beta)$ and ringwoodite $(\beta), T=1400^{\circ} \mathrm{C}$.

\begin{tabular}{lcccc}
\hline Run No. & Pressure & \multicolumn{2}{c}{$\mathrm{H}_{2} \mathrm{O}$ wt $\%$} & \\
\cline { 3 - 4 } & $(\mathrm{GPa})$ & $\beta$ & $\gamma$ & \\
\hline E1788-1 & 16.1 & 3.72 & 1.69 & 2.20 \\
E1760-1 & 16.3 & 2.28 & 1.11 & 2.05 \\
E1760-2 & 16.3 & 2.24 & 1.25 & 1.79 \\
E1751-1 & 16.5 & 1.88 & 1.00 & 1.88 \\
E1751-2 & 16.5 & 1.79 & 1.10 & 1.63 \\
average & & & & $1.9(2)$ \\
\hline
\end{tabular}

$K_{d}=\left(\mathrm{H}_{2} \mathrm{O}\right)_{\beta} /\left(\mathrm{H}_{2} \mathrm{O}\right)_{\gamma}$ 


\section{3 ポストスピネル相転移における水の分配}

この相転移境界は $660 \mathrm{~km}$ 地震波速度不連続面に 対応していると考えられており，マントル遷移層と 下部マントル間の水の分配に対応する。

実験は $\left(\mathrm{Mg}_{0.8} \mathrm{Fe}_{0.2}\right)_{2} \mathrm{SiO}_{4}$ 組成のカンラン石に水を 加えた系で行なった。 ringwoodite と perovskite の共 存領域で実験を行ない，これらの共存相それぞれの 含水量を二次イオン質量分析計で分析した。結果は Table 3.に示す通りで, ringwoodite-perovskite 間の 水の分配には非常にばらつきはあるが約 $15: 1$ となっ た。すなわち, $660 \mathrm{~km}$ 不連続面を介して, マント ル遷移層の方が下部マントルより水が約 15 倍程度 多く含まれることになる。この見積もりにはまだ問 題も多く，この值は予備的なものである。その理由 は, perovskite 中の含水量の少なさに由来している。 しかしいずれにせよ，下部マントル中にはほとんど 水が含まれないことが分かる。

Table 3. $\mathrm{H}_{2} \mathrm{O}$ partitioning between ringwoodite $(\gamma)$ and perovskite (pv), $T=1600^{\circ} \mathrm{C}$.

\begin{tabular}{ccccc}
\hline Run No. & Pressure & \multicolumn{2}{c}{$\mathrm{H}_{2} \mathrm{O}$ wt $\%$} & \multirow{2}{*}{$K_{d}$} \\
\cline { 3 - 4 } & $(\mathrm{GPa})$ & $\gamma$ & $\mathrm{pv}$ & \\
\hline E1784 & 23.03 & 0.76 & 0.06 & 13 \\
E1730 & 23.04 & $0.71(25)$ & 0.03 & $24(8)$ \\
E1695 & 23.05 & $0.63(11)$ & $0.07(3)$ & $9(5)$ \\
average & & & & $15(8)$ \\
\hline
\end{tabular}

$K_{d}=\left(\mathrm{H}_{2} \mathrm{O}\right)_{\gamma} /\left(\mathrm{H}_{2} \mathrm{O}\right)_{\mathrm{pv}}$

\section{4. 地球内部の含水量の見積もり}

前章ではマントル中の不連続面を介して，相対的 に水がどの程度含まれるかを論じた。では, 実際の 地球内部にはどの程度の水が含まれるのであろうか。 この問題を明らかにするためには，1つには地震学 から得られた地球内部構造デー夕と高圧実験から得 られた物性デー夕を比較することによって可能にな ると考えられる。

地震学からは, マントル中の不連続面の深さ, 及 び速度構造が精度良く求められうる情報であり, 高 圧実験からはカンラン石の相転移の圧力, 及び各高 圧相の熱弾性的性質がこれらの情報に対応する。よっ てカンラン石の高圧相転移境界に及ぼす水の影響, またカンラン石の高圧相の熱弾性的性質に及ぼす水 の影響を知れば, 地震学的情報と対応させ, 地球内
部での水の存在量が制約されうるであろう。このよ うな理由から, 筆者らは, 上記の物性における水の 影響を求めてきた。以下にその結果について簡単に 紹介する。

\section{1 カンラン石の高圧相転移境界に及ぼす水の影 響}

olivine-wadsleyite 相転移境界における水の影響は, その境界を低圧側に移動させることが明らかとなっ た[12]。その程度は wadsleyite 中に水が $3 \mathrm{wt} \%$ 含ま れた場合, マントルオリビン組成では $0.3 \mathrm{GPa}$ 程度 である（地球内部では約 $9 \mathrm{~km}$ に相当）。また，相 転移幅は無水の $0.6 \mathrm{GPa}$ から $0.3 \mathrm{GPa}$ へ之非常にシャー プな不連続面になることが明らかとなった。

一方, wadsleyite-ringwoodite 相転移境界における 水の影響は，その境界を高圧側に移動させることが 明らかとなった。その程度は含水量が $1 \mathrm{wt} \%$ の場 合，マントルオリビン組成では $0.5 \mathrm{GPa}$ 程度である (地球内部では約 $15 \mathrm{~km}$ に相当)。また，相転移幅 はまだ十分制約されたとはいいがたいが，無水の $1.5 \mathrm{GPa}$ から少なくともその半分以下へと, よりシャー プな不連続面になることが明らかとなった。

さらにポストスピネル相転移境界における水の影 響は，その境界を高圧側に移動させることが明らか となった[14]。その程度は含水量が $3 \mathrm{wt} \%$ の場合, $0.2 \mathrm{GPa}$ 程度とごくわずかである（地球内部では約 $6 \mathrm{~km}$ に相当)。また，相転移幅は鉄を含んだ系では まだ明らかにされていないので詳しいことは言えな いが, 我々の予備的な結果から, 無水同様, 非常に シャープな不連続面になりそうである。

これらの結果はそれぞれの相間の水の分配から理 解できる。すなわち, wadsleyite は olivine 及び ringwoodite より多く水を保持できるので，その分 安定領域が広がることになる。また ringwooditeに は perovskite や ferropericlase より多く水を保持でき るので，その安定領域は広がることになる。相図を 用いたこの解釈は省略するが，上記の実験結果はこ の解釈と一致する。

\section{2 カンラン石の高圧相の熱弾性的性質に及ぼす 水の影響}

前述のように，カンラン石の高圧相である wadsleyite, ringwoodite には最大 $3 \mathrm{wt} \%$ も水が結 晶構造中に含まれうることが明らかになり，これに 伴い，熱弾性的性質も大きく変化するはずである。 
このような理由から hydrous wadsleyite, hydrous ringwoodite の弾性定数, 及び熱膨張率を求めた。

hydrous wadsleyite の弾性定数は現在のところ体 積弾性率のみ決定されており, 含水量 $2.5 \mathrm{wt} \%$ の のでその值は $155 \mathrm{GPa}$ 程度である $[15,16]$ 。これは 無水のものの值 $172 \mathrm{GPa}[17]$ に比べて約 10\%小さい。 剛性率の結果はまだ得られていない。一方熱澎張率 は $30.1 \times 10^{-6} / \mathrm{K}$ で無水のものの值 $34.0 \times 10^{-6} / \mathrm{K}$ に比 べて約 11\%小さい[18]。

hydrous ringwoodite の弾性定数は含水量 $2.2 \mathrm{wt} \%$ のもので $155 \mathrm{GPa}[11]$, 含水量 $2.8 \mathrm{wt} \%$ あので $148 \mathrm{GPa}[19]$ であり，これは無水のものの值 $184 \mathrm{GPa}[20]$ に比べてそれぞれ約 16\%, 約 20\% む小 さい。含水量の増加による体積弾性率の減少は 1 次 の良い相関がある。一方, 剛性率の結果は含水量 $2.2 \mathrm{wt} \%$ もので求められており, その值は $107 \mathrm{GPa}[11]$ である。これは無水のものの值 $119 \mathrm{GPa}[20]$ に比べて約 10\%小さい。一方熱膨張率 は $27.3 \times 10^{-6} / \mathrm{K}$ で無水のものの值 $30.7 \times 10^{-6} / \mathrm{K}$ に比 べて約 11\%小さい[18]。

\section{3 地球内部の含水量}

今まで述べてきた物性デー夕を使って, 地球内部 の含水量を推定してみよう。

まず最初に $410 \mathrm{~km}$ 不連続面の速度ジャンプの幅 に着目する。この不連続面はカンラン石の olivinewadsleyite 転移に対応しているので, この相転移に おける速度ジャンプを見積もる必要がある。地震学 的観測によれば，この境界における速度ジャンプは $4.6 \%$ 程度である $[21,22]$ 。一方, 最近の超音波速度 測定を使って求められた弾性波速度デー夕と比較す ると, この付近のカンラン石の量は 38 から $39 \%$ と 見積もられている[17]。この值は地球のマントルが パイロライト的（カンラン石の量が約 60\%）であ るという考えとは一致しない。同様な見積もりは, Duffy and Anderson[23]によってもなされている。

上記の結論はマントルを無水マントルと仮定した ものであり，マントルに水が加わっているとすれば, この結論は変わってくる。olivine に比べ wadsleyite には 5 倍水が加わり, 且つ wadsleyite の弾性波速度 は水が加われば遅くなる傾向にあるので, この不一 致を解消することになる。よって我々は最近求めた hydrous wadsleyite の熱弾性的データを使ってこの 不連続面の速度ジャンプを含水量の関数として見積 もった[18]。その結果を Fig. 1 に示す。この計算に
は我々が最近もとめた wadsleyite, hydrous wadsleyite の熱膨張率, 及び含水量 $2.4 \mathrm{wt} \%$ とした ときの弾性定数を使っている。また剛性率は求まっ ていないので, 今回はバルク音速での議論である。 なお， wadsleyiteに比べ olivine には水がわずかしか 含まれないので，今回の計算では無水の olivine の 熱弾性的パラメータを使っている。

結果は，無水マントルでは Li et al.[17] に示され るように $60 \%$ olivine のパイロライトマントルでは $410 \mathrm{~km}$ での地震波速度のジャンプを説明できない が，水が加わればこの速度コントラストを低減し， 約 $1.5 \mathrm{wt} \%$ の水が wadsleyite に加わったマントルを 考えれば説明できる結果となった。この結果と前述 したマントル中の水の分配を考慮すると, olivine には約 $0.3 \mathrm{wt} \%$, wadsleyite には約 $1.5 \mathrm{wt} \%$, ringwoodite には約 $0.75 \mathrm{wt} \%$, perovskite には約 $0.05 \mathrm{wt} \%$ となる。パイロライトではカンラン石は 60\%の量を占め, その他のキ石やザクロ石にはほと んど水が含まれないことを考慮すると，マントル中 の含水量は, 上部マントルで約 $0.18 \mathrm{wt} \%$ ，マント ル遷移層の 410-520 km 間で約 0.9 wt\%， 520 $660 \mathrm{~km}$ 間で約 $0.45 \mathrm{wt} \%$ ，下部マントルでは約 $0.035 \mathrm{wt} \%$ となる（Fig. 2.）。

さらに最近, 末次ら[24]によりフィリピン海マン トル遷移層の温度及び含水量の同時推定が以下のよ うな手法で行なわれた。地震学的に推定された

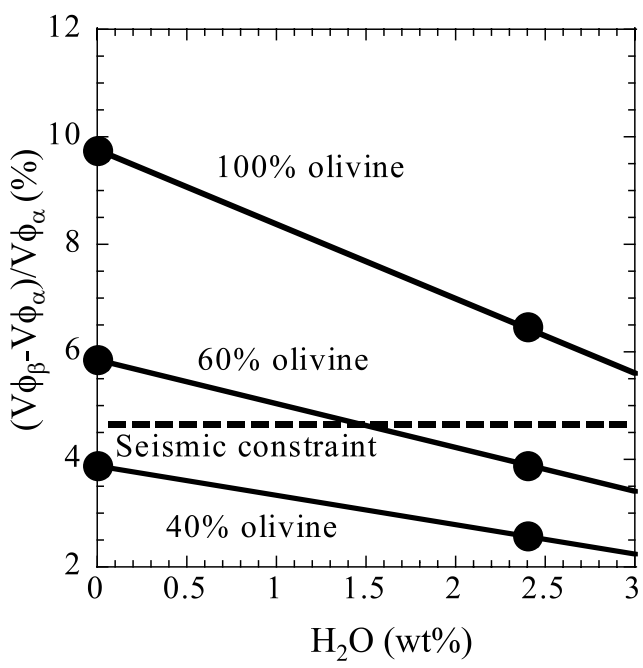

Fig. 1. The bulk sound velocity contrast at $410 \mathrm{~km}$ discontinuity corresponding to $\sim 13.5 \mathrm{GPa}$ and $\sim 1400^{\circ} \mathrm{C}$ as a function of $\mathrm{H}_{2} \mathrm{O}$ and olivine content $(100 \%, 60 \%$ and $40 \%)$. Horizontal broken line indicates the seismic contrast from Benz and Vidale (1993) and Nolet et al. (1994). 
$660 \mathrm{~km}$ 付近の $\mathrm{P}$ 波速度と不連続面の深さを，高压 実験から推定されたポストスピネル転移による $\mathrm{P}$ 波速度と相転移境界の温度及び含水量依存と組み合 わせて，連立方程式を解くという手法である。地震 学的デー夕, 及び物性パラメータそれぞれに䛊差が あるため得られた結果にも大きな䛊差が含まれては いるが, 研究対象となったマリアナトラフ, パレス ベラ海盆, 及び大東海嶺下の $660 \mathrm{~km}$ 直上のマント 儿遷移層で $350-500^{\circ} \mathrm{C}$ 程度温度が低く， かつ 0.7$1.0 \mathrm{wt} \%$ 周囲のマントルより水に富んでいるという 結果が得られている。この付近は沈み込んだ太平洋 プレートが横たわっている箇所であり，この結果は スラブの沈み込みによりマントル遷移層まで水が運 搬されていることを示している。

(a)

$\alpha \quad 0.3 \mathrm{wt} \% \quad 0.18 \mathrm{wt} \%$

$410 \mathrm{~km}$

$520 \mathrm{~km}$\begin{tabular}{ccc}
$\beta$ & $1.5 \mathrm{wt} \%$ & $0.9 \mathrm{wt} \%$ \\
\hline
\end{tabular}

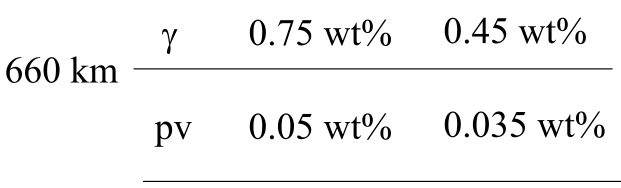

Fig. 2. The $\mathrm{H}_{2} \mathrm{O}$ partitioning between upper mantle, mantle transition zone and lower mantle. $\alpha$ : olivine, $\beta$ : wadsleyite, $\gamma$ : ringwoodite, pv: perovskite. (a) The $\mathrm{H}_{2} \mathrm{O}$ concentrations in olivine high-pressure polymorphs. (b) The $\mathrm{H}_{2} \mathrm{O}$ concentrations in each layer. See text in details.

\section{5. おわりに}

本論文では地球内部の水の分配に関して, 特にマ ントル遷移層を境界に, 上部マントル, 下部マント ルに相対的によ゙れだけ水が含まれるか，さらには $410 \mathrm{~km}$ のジャンプ幅とパイロライトモデルを採用 することにより，絶対值としてどれくらい水が含ま れるかを考察してきた。しかしながらこれらの推定 にはまだ不確定要素が多く,さらに詳しい検討が必 要である。特に, ringwoodite と perovskite 間の $\mathrm{H}_{2} \mathrm{O}$ の分配は perovskite 中への $\mathrm{H}_{2} \mathrm{O}$ の固溶が少ないため 二次イオン質量分析計での測定には限界があり, 今 後他の方法（例えば赤外分光装置による低濃度 $\mathrm{H}_{2} \mathrm{O}$ 量の測定）による測定も必要と思われる。また, hydrous wadsleyite の剛性率はまだ決まっていない ので,この值を求める必要がある。さらには地球全 体に渡る不連続面の速度ジンプ幅, 及び深さの分 布が今回示した推定法に耐えうる精度で決定される 必要がある。これらのデータが出揃えば，地球内部 の含水量のマッピングがマントル遷移層を中心とし て可能となると思われる。最後に，今回は核に溶存 する水（水素）の議論はしていない。Fukai[25]や Okuchi[26]によれば，かなりの量の水素が核に溶存 していると議論している。このように，下部マント ルと核との水素分配も非常に重要である。

\section{謝 辞}

本論文に対して有益なコメントをいただいた匿名 の査読者に感謝いたします。また本論文は 2003 年 10 月 14-15 日にわたって開催された「超高圧流体 反応研究会」(京都大学地球熱学研究施設 (別府) で開催）での筆者の講演を基にまとめられた。この 研究集会を企画していただき，この論文の執筆の機 会を与えていただいた遊佐斉博士に深く謝意を表し ます。

\section{参考文献}

[1] 井上徹: 地震, 48, 167 (1995).

[2] 井上徹: 鉱物学雑誌, 27, 57 (1998).

[3] 井上徹: 地球化学, 33, 207 (1999).

[4] 井上徹: 高圧力の科学々技術, 10, 124 (2000).

[5] A.E. Ringwood: Geochem. J., 11, 111 (1977).

[6] P.E. Fricker, R.T. Reynolds: Icarus, 9, 221 (1968).

[7] Y. Abe, T. Matsui: J. Geophys. Res., 90, C545 (1985).

[8] Y. Abe, T. Matsui: J. Geophys. Res., 91, E291 (1986).

[9] K. Kuramoto, T. Matsui: J. Geophys. Res., 101, 14909 (1996).

[10] T. Inoue, H. Yurimoto, Y. Kudoh: Geophys. Res. Lett., 22, 117 (1995).

[11] T. Inoue, D.J. Weidner, P.A. Northrup, J.B. Parise: Earth Planet. Sci. Lett., 160, 107 (1998).

[12] J. Chen, T. Inoue, H. Yurimoto, D.J. Weidner: Geophys. Res. Lett., 29, 1875 (2002).

[13] T. Kawamoto, R.L. Hervig, J.R. Holloway: Earth Planet. Sci. Lett., 142, 587 (1996).

[14] Y. Higo, T. Inoue, T. Irifune, H. Yurimoto: Geophys. Res. Lett., 28, 3505 (2001).

[15] H. Yusa, T. Inoue: Geophys. Res. Lett., 24, 1831 (1997). 
[16] Y. Kudoh, T. Inoue: in High Pressure-Temperature Research: Properties of Earth and Planetary Materials, eds. M.H. Manghnani, T. Yagi (AGU, 1998), p. 517.

[17] B. Li, R.C. Liebermann, D.J. Weidner: Science, 281, 675 (1998).

[18] T. Inoue, Y. Tanimoto, T. Irifune, T. Suzuki, H. Fukui, O. Ohtaka: Phys. Earth Planet. Inter. (2004); (in press).

[19] H. Yusa, T. Inoue, Y. Ohishi: Geophys. Res. Lett., 27, 413 (2000).

[20] D.J. Weidner, H. Sawamoto, S. Sasaki, M. Kumazawa: J. Geophys. Res., 89, 7852 (1984).
[21] H.M. Benz, J.E. Vidale: Nature, 365, 147 (1993). [22] G. Nolet, S.P. Grand, B.L. Kennett: J. Geophys. Res., 99, 23753 (1994).

[23] T.S. Duffy, D.L. Anderson: J. Geophys. Res., 94, 1895 (1989).

[24] 末次大輔, 塩原肇, 小野重明, 井上徹, 大林政行, 杉岡裕子, 小平秀一, 深尾良夫, 望月公廣, 金沢敏 彦，日野亮太，斉田智治：日本地震学会 2003 年度 秋季大会予稿集.

[25] Y. Fukai: Nature, 308, 174 (1984).

[26] T. Okuchi: Science, 278, 1781 (1997).

[2004 年 3 月 8 日受理] 